\title{
RELATIONSHIP OF PEER INFLUENCE AND FAMILY EATING HABITS ON HEALTHY FOOD CHOICES IN OVERWEIGHT ADOLESCENTS IN SURAKARTA
}

\author{
Khairunnisa Nadya Risti ${ }^{*}$, Eti Poncorini Pamungkasari², Suminah ${ }^{3}$ \\ ${ }^{1}$ The Study Program of Nutrition Science, Master's Degree Program, Universitas Sebelas Maret, Surakarta, Indonesia \\ ${ }^{2}$ The Study Program of General Medicine, Faculty of Medicine, Universitas Sebelas Maret, Surakarta, Indonesia \\ ${ }^{3}$ The Study Program of Agricultural Extension and Communication, Faculty of Agriculture, Universitas Sebelas Maret, Surakarta, \\ Indonesia \\ *E-mail: dheanadya97@gmail.com
}

\begin{abstract}
Unhealthy eating habits among Indonesian occur not only in adults, but also in adolescents. Adolescence is a transitional period and most easily affected by the surrounding environment. Environmental influences such as peer influence and family eating habits are dominant factors for food they choose to consume. This study aimed at analyzing the relationship of peer influence and family eating habits on healthy food choices in overweight adolescents in Surakarta. It used observational study with cross sectional approach. Random sampling was used to determine its samples, consisting of 96 respondents. The data of peer influence, family eating habits, and healthy food choices were collected through structured questionnaires. They were analyzed by using the Pearson Product Moment statistical test. The results indicated that there is a relationship between peer influence and healthy food choices in overweight adolescents in Surakarta $(p=0.014 ; \mathrm{r}=-0.250)$; and there is a significant relationship between family eating habits and healthy food choices in overweight adolescents in Surakarta $(p=0.011 ; \mathrm{r}=0.258)$.
\end{abstract}

Keywords: Adolescents, Overweight, Healthy food choices, Peer, Family

\section{INTRODUCTION}

Health problems currently encountered by Indonesian people include diseases caused by poor lifestyle. Non-communicable diseases, largely brought about by unhealthy lifestyle, namely high sugar, salt, and fat consumption rate, can lead to the prevalence of overweight and obesity that can occur not only in adults, but also in adolescents. Overweight in adolescents can occur due to the high levels of consumption of sweet, salty, fatty and low-fiber foods causing higher prevalence of overweight than underweight (World Health Organization, 2018).

The prevalence of overweight and obesity in children and adolescents increased significantly from $4 \%$ in 1975 to $18 \%$ in 2016 . The increase occurred equally between girls and boys (World Health Organization, 2018). In Indonesia, the prevalence of overweight in adolescents aged 1519 years old in 2018 was $9.5 \%$, in Central Java was $7.9 \%$, while that in Surakarta was $9.98 \%$. This figure was inseparable from the factor of poor food choices among adolescents aged 15-19 years old as they regularly consumed sweet foods $(41.0 \%)$, sweet drinks $(56.43 \%)$, salty foods $(30.5 \%)$ and fatty foods (43.8\%) more than once a day (Ministry of Health Indonesia, 2018).

Adolescence is a transitional period from childhood to adulthood. This period often causes various impacts, including health problems. During transitional process, the issue of doubt often arises among adolescents. Thus, environmental factor plays a crucial role in the choice of foods consumed. Peer influence and family eating habits are dominant factors in determining food intake among adolescents. The study conducted by Yee et al. (2017) stated that families, especially parents, have a significant effect on the consumption of healthy and unhealthy foods among adolescents. In addition, the study revealed that family is the most important social influence as a means of health promotion, role models, and education in influencing the food choices of children and adolescents. Meanwhile, the study conducted by Martin et al. (2018) stated that peer influence can provide information that increases healthy food choices. In contrast, the study conducted by Fitri (2018) revealed that peer influence has an effect on 
food choices of adolescents, but in that research, the higher peer influence causes less healthy food choices. This occurs because adolescents spend most of their time with age-equivalent peers during transitional period, so that they easily absorb information from various sources that has not been scientifically proven to be true. This is also supported by various influential factors such as age, gender, pocket money, and family income.

Thus, the researchers are interested in analyzing the relationship of peer influence and family eating habits on healthy food choices in overweight adolescents in Surakarta.

\section{METHOD}

This research design used observational analytic design with cross sectional approach conducted from February to March 2020. Its subjects were senior high school students in Laweyan, Banjarsari and Jebres sub-districts, Surakarta who met the criteria. Based on the screening results of senior high school students by the Health office of Surakarta in 2018, there were 114 teenagers overweight in Laweyan sub-district, 45 in Jebres sub-district and 65 in Banjarsari subdistrict. Inclusion criteria for this research were senior high school students aged 15-17 years and living in Surakarta, having an overweight nutritional status ( $\geq 1 \mathrm{SD} \mathrm{BMI} / \mathrm{A} \mathrm{Z}$-Score), and having no illness in the last 3 months. Its population was 120 . Random sampling was used to determine its samples. They consisted of 96 students.

Before the study was conducted, the screening process had been carried out. It began with measuring the Body Weight (BW) by using a digital scale with the accuracy of $0.1 \mathrm{~kg}$ and the Height $(\mathrm{H})$ by using a microtoice with the accuracy of $0.1 \mathrm{~cm}$. The screening process was aimed to assess the nutritional status of the adolescents. Nutritional status assessment used WHO AnthroPlus software (Z-Score, IMT/U). The Z-Score values obtained were categorized based on growth categories from the World Health Organization 2007, consisting of normal (-2 SD to $1 \mathrm{SD}$ ), overweight ( $>1 \mathrm{SD}$ to $2 \mathrm{SD}$ ), obese ( $>2$ SD) (World Health Organization, 2007).
Data on peer influence, family eating habits, and healthy food choices were obtained from the self-assessment process, where respondents filled out questionnaires that had been tested for validity and reliability with the guidance from researchers. The family eating habits questionnaire, peer influence, and healthy food choices were made by researchers. Questions in the family eating habits questionnaire included those of how often the respondents eat together with their family members, what foods are usually available at home, and whether or not there are restrictions or supports from parents in consuming certain foods. Meanwhile, the questions in peer influence included those of how frequent the respondents eat together with friends, what foods friends recommend them to consume, and how often they follow consuming what is eaten by friends. Healthy food selection consisted of thirty-five questions covering aspects of health, comfort, sensory, natural content in food, prices, and ethical issues. Peer influence variable consisted of nine questions with the value of Cronbach Alpha of 0.725 . Family eating habits consisted of five items with the value of Cronbach Alpha of 0.758 , and healthy food choices consisted of thirty-five questions with the value of Cronbach Alpha of 0.948 .

Univariate analysis was performed with cross tabulation analysis which was aimed to display descriptive data for each variable while bivariate analysis was performed on two variables, namely: peer influence variable on food choices and family eating habits on food choices using the Pearson Product Moment (PPM) test because the data were normally distributed. Further, multivariate analysis was performed by using a multiple linear regression test to investigate the level of influence of each independent variable on the dependent variable. This study passed ethical review from Health Research Ethics Commission (KEPK) of Universitas Sebelas Maret No.035/UN27.06.6.1/ KEPK/EC/2020.

\section{RESULT AND DISCUSSION}

Based on the results of the study, data on age, gender, pocket money, parental occupation and parental income were obtained. Distribution of 
characteristics of 96 respondents in this study are presented Table 1.

Majority of the overweight subjects (50\%) are aged 16 years old. The distribution of respondents by gender indicated that the percentage of female students is $59.4 \%$ (57) higher than the percentage of male students by $40.6 \%$ (39). Females tend to be more overweight and obese than males because females store energy in the form of fat, while males use excess energy for protein synthesis (Oktaviani et al., 2012). The risk of overweight and obesity in females has also doubled compared to that of overweight and obesity in males along with the increasing age (Noh et al., 2014).

Adolescence is a transitional period from childhood to adulthood. Physical changes in this period affect and change the body's nutritional needs (Saribay \& Kirbas, 2019). During this transitional period, adolescents find it difficult to choose healthy foods. Most adolescents think that

Table 1. Distribution of Characteristics of Respondents

\begin{tabular}{|c|c|c|}
\hline Variable & Amount (n) & Percentage $(\%)$ \\
\hline \multicolumn{3}{|l|}{ Age (year) } \\
\hline 15 & 27 & 28.1 \\
\hline 16 & 48 & 50.0 \\
\hline 17 & 21 & 21.9 \\
\hline Total & 96 & 100 \\
\hline \multicolumn{3}{|l|}{ Gender } \\
\hline Male & 39 & 40.6 \\
\hline Female & 57 & 59.4 \\
\hline Total & 96 & 100 \\
\hline \multicolumn{3}{|l|}{ Pocket Money } \\
\hline$<\operatorname{Rp} 10.000$ & 9 & 9.4 \\
\hline Rp 10.000-20.000 & 17 & 17.7 \\
\hline$>\operatorname{Rp} 20.000$ & 70 & 72.9 \\
\hline Total & 96 & 100 \\
\hline \multicolumn{3}{|l|}{ Parental Occupation } \\
\hline Private Employee & & \\
\hline Civil Servant & $\begin{array}{l}27 \\
13\end{array}$ & $\begin{array}{l}28.1 \\
13.5\end{array}$ \\
\hline National Police & $\begin{array}{c}13 \\
1\end{array}$ & $\begin{array}{c}13.5 \\
1.0\end{array}$ \\
\hline Soldiers & 1 & 1.0 \\
\hline Entrepreneur & 54 & 56.3 \\
\hline Total & 96 & 100 \\
\hline \multicolumn{3}{|l|}{ Parental Income } \\
\hline$<\operatorname{Rp} 1.000 .000$ & 4 & 4.2 \\
\hline $\mathrm{Rp} 1.000 .000-\mathrm{Rp}$ & 56 & 58.3 \\
\hline 2.000 .000 & & \\
\hline$>\operatorname{Rp} 2.000 .000$ & 36 & 37.5 \\
\hline Total & 96 & 100 \\
\hline
\end{tabular}

healthy foods are tasty foods so that they prefer high-calorie foods such as sweet and low-fiber foods. This leads to weight gain in adolescents, if not followed by intense physical activities, such a state can increase the risk of overweight that leads to obesity.

Adolescents often make decisions to choose foods based on emotions rather than rationale. Food choices are driven by various external factors such as direct social environmental factors, namely: family and peers, and other factors, namely: school setting, the presence of fast-food outlets, customs/ habits, and pocket money (Thiruselvakumar et al., 2014). Adolescents with bigger pocket money tend to have a bigger autonomy in food choices (Araujo et al., 2017). Another study by Poulimeneas (2017) showed that pocket money is associated with BMI among male adolescents. The same finding was also found in this study, which confirms that biggest proportion of overweight is prevalent in the highest pocket money subjects. The distribution of respondents by pocket money in this study showed that more than half of total respondents or $72.9 \%$ (70 respondents) have a pocket money of $>\mathrm{Rp} 20.000$, this indicated that majority of respondents have a relatively large pocket money for high school adolescents. The big daily pocket money can increase the prevalence of overweight and obesity in adolescents (Rafiony et al., 2015). In addition, according to Ali \& Nuryani (2018), the large amount of pocket money has an effect on purchasing power. However, they tend to purchase the high quantity but low quality products. For example in food choices, during transitional period, adolescents tend to choose high-calorie foods which are risk factors for overweight and obesity in adolescents.

Most of the respondents' parents or 54 (56.3\%) work as entrepreneurs. The parental income or family income mostly ranges from Rp1.000.000 to Rp2.000.000 per month. Family income can be associated with reasons for choosing foods to be consumed in a family. High-income families can provide more nutritious and healthy food than low-income families. Low-income families usually consume less fruits and vegetables, more sugar sweetened beverages and low quality diet (French et al., 2019). 
Table 2. Relationship of Peer Influence, Family Eating Habits on Healthy Food Choices in Overweight Adolescents in Surakarta

\begin{tabular}{lccccc}
\hline \multicolumn{1}{c}{ Variable } & Minimum & Maximum & Mean \pm SD & P & R \\
\hline Healthy food choices score & 9.86 & 91.64 & $58.84 \pm 13.06$ & - & - \\
Peer influence & 5.04 & 24.07 & $14.17 \pm 3.96$ & 0.014 & -0.250 \\
Family eating habits & 3.82 & 15.58 & $9.44 \pm 2.38$ & 0.011 & 0.258 \\
\hline
\end{tabular}

Analysis of the relationship of per influence on food choices in adolescents is presented in Table 2. The correlation test using the Pearson Product Moment obtained the p-value of 0.014 $(<0.05)$, meaning that $\mathrm{H}_{0}$ is not verified or there is a relationship of peer influence on food choices of adolescents. According to Aisyiah (2015), school-age children, including adolescents, are easily influenced by the surrounding environment, especially peer influence. Peer influence is a social influence that can affect one's food intake. This refers to imitating behavior of others, both directly and indirectly (Thiruselvakumar et al., 2014; Kim et al., 2019). Peer influence is one of the reasons in choosing foods because adolescents spend more productive time outside their home, so that they often meet peers and share common understanding (Fitri, 2018).

The result of correlation analysis indicated that there is a relationship of peer influence on food choices of adolescents. This finding is in line with that of the study by Fitri (2018) that there is a relationship between peer influence and dietary behavior (which is also healthy food choices behavior). The result obtained OR of 3.725 , meaning that respondents affected by

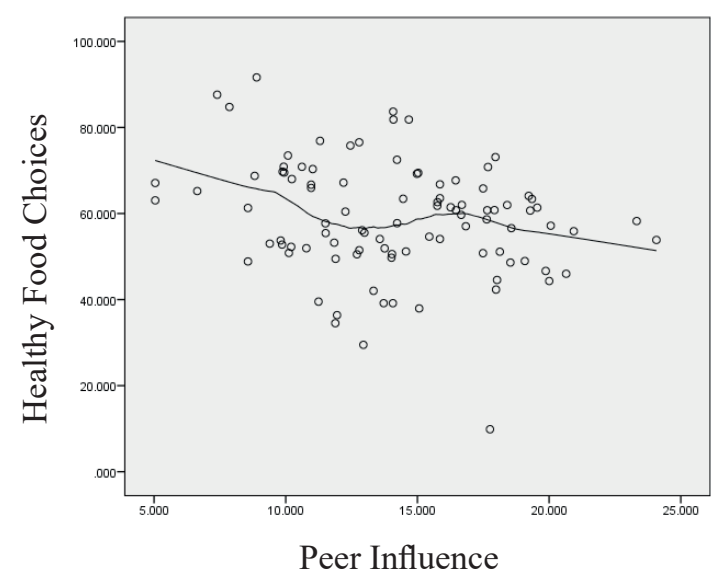

Figure 1. Scatter Plot of Peer Influence and Healthy Food Choices. their peers will be four times more at risk for an unhealthy diet. In other words, peer influence has a negative effect on food choices that lead to unhealthy foods.

Distribution of supporting data on a negative relationship between peer influence and healthy food choices can be seen in Figure 1. The line, which rises to the left explains that there is a negative linear relationship between peer influence and healthy food choices in overweight adolescents in Surakarta. The Pearson correlation test conducted in this study showed $r=-0.250$ which is greater than $r$ table $(r$ table $=0.198)$, meaning that the greater peer influence is, the lower the possibility of choosing daily healthy foods will be.

The test result of the relationship between family eating habits and healthy food choices of adolescents can be seen in Table 2. Based on correlation test using the Pearson test, the p-value was $0.011(<0.05)$, meaning that $\mathrm{H}_{0}$ is not verified, or there is a relationship between family eating habits and healthy food choices in overweight adolescents in Surakarta. Direction of relationship can be seen in Table 3 indicating a positive relationship with $r=0.258(\mathrm{r}$ table $=0.198)$.

The result of correlation test indicated a significant relationship. This finding is consistent with that of the study of Bargiota et al. (2013) that adolescents tend to follow their family eating habits because they are accustomed to the eating pattern in the family. The study stated that adolescents tend to follow what their parents do. If the family is accustomed to eating in restaurants, adolescents will tend to consume more fast foods such as pasta, pizza and other high-calorie foods. The result of this study is in accordance with Vandeweghe et al. (2016) stating that positive family habits can be part of promotion process and formation of healthy behavior. Families shall have positive eating habits such as providing healthy foods and support to engage in healthy eating behavior for children. 


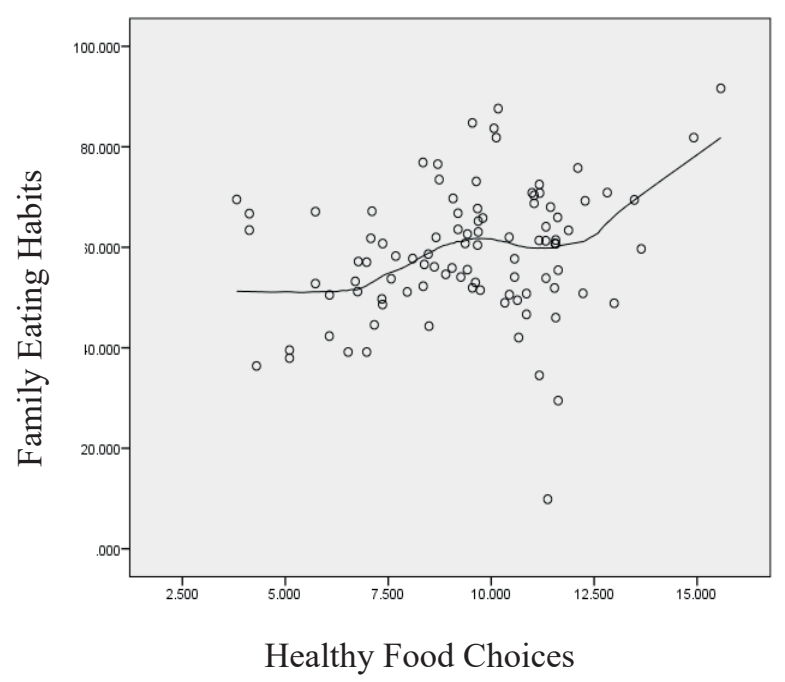

Figure 2. Scatter Plot of Family Eating Habits and Healthy Food Choices

Family eating habits are affected by interactions between individuals in a family. Condition of home environment, including accessibility and availability of different foods in each family is a key in the arrangement or selection of foods based on sociocultural aspect (Scaglioni et al., 2018). The study of McIntosh et al. (2011) stated that there is a positive relationship between family eating habits and consumption of healthy foods such as fruits, vegetables, and other foods that are rich in calcium and nutrients. Thus, good family eating habits provide a good example for adolescents to choose healthy foods both inside and outside home. Adolescents who eat with family were likely to have lower risk to eat unhealthy foods.

Figure 2 shows that the distribution of family eating habits and healthy food choices in adolescents indicated the direction of a positive linear relationship with $r=0.258$, meaning that if a family has good eating habits, adolescents will choose healthy foods in their daily lives.

The results of multiple linear regression analysis indicated that peer influence $(\mathrm{p}=$ $0.008)$ and family eating habits $(p=0.006)$ have a significant effect on healthy food choices in overweight adolescents with $\mathrm{R}$ Square value of 0.158 , meaning that peer influence and family eating habits have a contribution in healthy food choices in overweight adolescents by $15.8 \%$. Other people can profoundly affect one's opinions and decisions (Martin et al., 2018). Children emulate the behavior of role models, and as a result, the eating behavior of their peers and family eating habits are likely to influence their own eating behavior (Scaglioni et al., 2018; Binder et al., 2019).

As for the limitations in this study, there was no tracing of eating frequency and eating habits of adolescents with their families in terms of amount and variety of food, so that it cannot descriptively show family eating habits that can improve healthier food choices of adolescents.

\section{CONCLUSION AND RECOMMENDATION}

Peer influence and family eating habits have a significant correlation on healthy food choices in overweight adolescents. Peer influence have a negative relationship on healthy food choices of adolescents, meaning that the greater negative peer influence, the lower possibility of choosing healthy foods in daily life ( $p=0.014 ; \mathrm{r}=-0.250)$. Family eating habits have a significant and positive relationship on healthy food choices $(\mathrm{p}=0.011 ; \mathrm{r}=$ 0.258 ). Adolescents should be able to control their food consumption. For schools, regular nutrition education for adolescents is required so that peer influence among adolescents has a positive effect in choosing daily food consumed. Thereby, the number of overweight adolescents in Indonesia can be suppressed.

\section{REFERENCES}

Aisyiah. (2015). Pola asuh dan pengaruh teman sebaya terhadap pemilihan jajanan anak usia sekolah di Kelurahan Cirendeu Tangerang Selatan. Jurnal Care 3(2), 1-8.

Ali R., \& Nuryani (2018). Sosial ekonomi, konsumsi fast food dan riwayat obesitas sebagai faktor risiko obesitas remaja. Media Gizi Indonesia, 13(2), 123-132. doi: 10.20473/mgi. v13i2.123-132.

Araujo, M.C., Cunha, D.B., Bezerra, I.N., \& de Castro, M.B.T. (2017). Quality of food choices of Brazilian adolescents according to individual earnings. Public Health Nutrition: 20(17), 3145 3150. doi: 10.1017/S1368980017002099.

Bargiota A., Delizona M., Tsitouras A., \& Koukoulis G.N. (2013). Eating habits and factors affecting food choice of adolescents living in rural areas. 
HORMONES, 12(2), 246-253. doi: 10.14310/ horm.2002.1408.

Binder A., Naderer B., \& Matthes J. (2019). Do children's food choices go with the crowd? Effects of majority and minority peer cues shown within an audiovisual cartoon on children's healthy food choice. Social Science \& Medicine, 225. 42-50. doi: 10.1016/j. socscimed.2019.01.032.

Fitri, R.P. (2018). Pengaruh teman sebaya, pengetahuan, media masa terhadap perilaku diet mahasiswi STIKES Payung Negei Pekanbaru. Jurnal Endurance 3(1). 162-168. doi : 10.22216/ jen.v3i1.1487.

French, S.A., Tangney C.C., Crane M.M., Wang Y., \& Appelhans B.M. (2019). Nutrition quality of food purchases varies by household income: the SHoPPER study. BMC Public Health. 19(1), 1-7:231. doi: 10.1186/s12889-019-6546-2.

Kim, E.B., Chen C., \& Cheon B.K. (2019). Using remote peers' influence to promote healthy food choices among preschoolers. Developmental Psychology, 55 (4), 703-708. doi: 10.1037/ dev0000669.

Martin R.E., Villanueva Y., Stephano T., Franz P.J., \& Ochsner K.N. (2018). Social influence shifts valuation of appetitive cues in early adolescence and adulthood. J Exp Psychol Gen. 147(10), 1521-1530. doi: 10.1037/xge0000469.

McIntosh A., Kubena K., Tolle G., Dean W., Kim M.J., Jan J.S., \& Anding J. (2011). Determinants of children's use of and time spent in fast-food and full service restaurants. J.Nutr. Educ. Behav., 43, 142-149. doi: 10.1016/j.jneb.2010. 04.002 .

Ministry of Health Republic of Indonesia. (2018). Riset Kesehatan Dasar. Jakarta: National Institute of Health Research and Development, Ministry of Health Republic of Indonesia

Noh J-W., Jo M., Huh T., Cheon J., and Kwon Y.D. (2014). Gender differences and socioeconomic status in relation to overweight among Korean people. PLOS ONE. 9(5) 1-9:e97990. doi: 10.1371/journal.pone.0097990.

Oktaviani W.D., Saraswati L.D., \& Rahfiludin M.Z. (2012). Hubungan kebiasaan konsumsi fast food, aktivitas fisik, pola konsumsi, karakteristik remaja dan orang tua dengan indeks masa tubuh (IMT) (Studi Kasus Pada Siswa SMA Negeri 9 Semarang Tahun 2012). Jurnal Kesehatan Masyarakat 1(2), 542-553. Retrieved from http://ejournals1.undip. ac.id/ index.php/jkm.
Poulimeneas D., Vlachos D., Maraki M.I., Daskalou E., Grammatikopoulou M., Karathano L., Kotsias E., Tsofliou F., Tsigga M., \& Grammatikopoulou M.G. (2017). Diet quality, overweight and daily monetary allowance of Greek adolescents. International Journal of Adolescent Medicine and Health, 31(3). doi: 10.1515/ijamh-2017-0019.

Rafiony A., Purba M.B., \& Pramantara I.D.P. (2015). Konsumsi fast food dan soft drink sebagai factor risiko obesitas pada remaja. Jurnal Gizi Klinik Indonesia, 11(4), 170-178.

Saribay A.K., \& Kirbas S. (2019). Determination of Nutrition Knowledge of Adolescents Engaged in Sports. Universal Journal of Educational Research 7(1):40-47. doi: 10.13189/ ujer.2019.070106.

Scaglioni S., Cosmi V.D., Ciappolino V., Parazzini F., Brambilla P., \& Agostoni C. (2018). Factors influencing children's eating behaviours. Nutrients, 10, 706; 1-17. doi:10.3390/ nu10060706.

Thiruselvakumar D., Sinuvasan K., Sibi C.R., \& Venkatesh E. (2014). Factors affecting food choices and attitude of choosing food items among adolescents in South India. International Journal of Scientific and Research Publication, 4(4), 1-3.

Vandeweghe L., Moens E., Braet C., Van Lippevelde W., Vervoort L., \& Verbeken S. (2016). Perceived effective and feasible strategies to promote healthy eating in young children: Focus groups with parents, family child care providers and daycare assistants. BMC Public Health, 16, 1045, 1-12. doi: 10.1186/s12889-016-3710-9.

World Health Organization. (2007). Growth reference 5-19 years. Retrieved from https:// www.who.int/growthref/who2007bmi_for_age/ en/.

World Health Organization. (2018). Obesity and overweight. Retrieved from https://www.who. int/news-room/fact-sheets/detail/ obesity-andoverweight.

Yee A.Z.H., Lwin M.O., \& Ho S.S. (2017). The influence of parental practices on child promotive and preventive food consumption behaviors: a systematic review and metaanalysis. International Journal of Behavioral Nutrition and Physical Activity. (1):47. 1-14 doi: 10.1186/s12966-017-0501-3. 